\title{
Napoleon w poezji środowiska akademików krakowskich
}

Jacek Wójcicki 


\section{nAPIS Seria XIII 2007}

\section{Jacek Wójcicki}

\section{Napoleon w poezji środowiska akademików krakowskich}

$\mathrm{P}$

rezentowany poniżej zestaw mało znanych utworów wierszowanych, związanych z bezpośrednimi i pośrednimi skutkami działań i decyzji największego bohatera dziejów świata przełomu XVIII i XIX wieku, pochodzi z jednego, w wyraźny sposób terytorialnie i profesjonalnie określonego środowiska — kręgu intelektualnego oddziaływania Akademii Krakowskiej. Nawet na tym drobnym wycinku okolicznościowej produkcji literackiej można dostrzec różnorodność zarówno pisarskich postaw mentalnych, jak i stosowanych przez autorów rozwiązań formalnych. Nie jest to wprawdzie wachlarz zbyt barwny ani za szeroki — nie sposób znaleźć w nim ani szyderczo groteskowej deprecjacji, ani wzniośle gloryfikującej mistyki, czyli emocji biegunowych (raczej trudno byłoby spodziewać się ich po trzeźwych, racjonalnych reprezentantach najstarszej polskiej uczelni), które zagoszczą niebawem na dobre w dziewiętnastowiecznej europejskiej i polskiej dyspucie publicznej na temat dziejowej roli Napoleona. Trudno też dostrzec eksperymenty wersyfikacyjne, chociażby na tak niewielka skalę, jak przejęcie przez Franciszka Wężyka' czy zwłaszcza przez Kajetana Koźmiana, twórcę szeroko znanych i wnikliwie już omówionych „ód napoleońskich”z, francu-

' Jako autora choćby Ody' na pourrót wojska polskiego do stolicy' d. 18 grndnia 1809 - zob. reprint w tece: Ulotna poezja patriotycana wojen napolconiskich (1805-1814), oprac. i przedm. A. Zieliński, Wroctaw 1977.

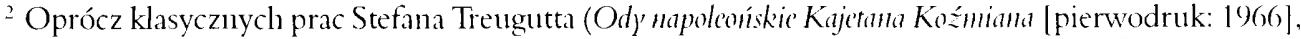
w: idem, Geninsz u'ydziedziczon). Studia romantyczne i mopoleoniskie, red. M. Prussak, Warszawa 1993, s. 35-93), Piotra Żbikowskiego - Kajetan Koźmian. I. Pocta i obyumatel (1797-1814), Wrocław 1972,

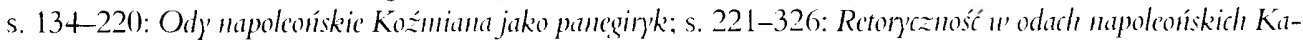

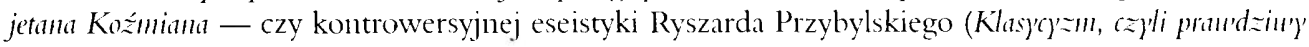


skiego wzorca dziesięciowersowej strofy jako wehikułu podniosłych, silnie zretoryzowanych wywodów - nie tyle może obrazujących rzeczywiste uczucia „podmiotów mówiących" (co było długi czas nieścisłym probierzem oceny tej zmiennej w stosunku do „Człowieka Wieku” poezji), ile na równi kanalizujących zastane nadzieje społeczeństwa polskiego i projektujących jego opinie wobec mniemanych wskrzesicieli dawnej narodowej świetności. Niemniej i w zgromadzonej tu grupie utworów znalazło się miejsce i na ewolucję wartościowania bohatera utworów — podobną nieco do tej, którą obserwować można na przestrzeni pomiędzy Odq na wojnę " roku 1800, ukoniczonq bataliq pod Marengo a Odq na upadek dumnego w rokn 1815 Koźmiana — i na systemowo znaczącą decyzję pisarzy o wyborze formy wierszowej.

Zarówno stosunkowo niedawne, choć zaledwie częściowe, włączenie jego wierszy w obieg naukowy, jak i wyrażoną przy tej okazji paralelę z Koźmianem, Erazm Komar, pierwszy z autorów poniższego zestawienia, zawdzięcza dwudziestowiecznemu monografiście kulturalnego życia regionu w „wieku światel”. Wcześniej zaś „tajemniczy poeta" (s. 117, 121), urodzony około roku 1770, żyjący jeszcze w roku 1827, o którym „jedynie przypuszczamy, że był ziemianinem” (s. 101), doczekał się od współczesnych famy libertyna, odludka i utracjusza. Jego skrótowy biogram (gdzie znalazło się miejsce i na konieczność ucieczki ze stanislawowskiej Warszawy za jakieś wiersze napisane przezeń po ścięciu Ludwika XVI, i na dwa zakazane prawem pojedynki, i nawet na porwanie mu zony przez wlasnego brata) w cytowanym przez Snopka liście z 12 czerwca 1802 roku do Józefa Sygierta (wybitnie zdolnego, wcześnie zmarłego literata i tłumacza, spiritus movens grupy mlodych wolnomyślicieli krakowskich) ${ }^{+}$barwnie ujął Lucjan Jakielski:

Jest on prawdziwy oryginał [...]. Inaczej go tu nie zowią, tylko dziwakiem, nosi kulczyki w uszach, głowę ostrzyżoną, i zawsze w jednym burym sur-

konier Królestu'n Polskicgn, Warszawa 1983, s. 285-322: Idzie num o u'szystko) z nowszych prac można wspomnié́: T. Kostkiewiczowa, $C z y^{\prime}$ „Ody' napolconiskie” Koźmiana sq cyklem poetyekim? Uwigi na temat "yznacznikón' cykliczności, w: Od Kochanou'skiego do Mickien'icza. Szkice o polskim cyklu poetyekim, red. B. Kuczera-Chachulska, Warszawa 2004, s. 144-160; Z. Libera, Napoleon " poczji polskiej na poczatku XIX wicku, w: idem, Od Scjmu Czicroletniego do Napoleona, red. M. Bokszczanin, przedm. T. Kostkiewiczowa, Warszawa 20()4, s. 24(1-249; W. Wojtowicz, Spes in Te. O „Odach napoleonskich" Kajetana Ko Emiana, „Prace Literackie” t. 47, red. M. Ursel, Wrocław 2007, s. 5-20.

${ }^{3}$ Zob. J. Snopek, Prou'incja ośu'iecona. Kultura literacka Ziemi Krakou'skiej u' dobic Ośüiccenia 1750-1815, Warszawa 1992, zwł. s 306-313: Inober legendy' napoleonskiej. Dalsze odwołania do książki Jerzego Snopka lokalizuję bezpośrednio w tekście.

+ Zob. J. Snopek, op. cit., zwl. s. 156-189, 257-264, 269-272; por. też: idem, Niezmana karta z dziejóu' ośuicceniou'ej recepgi literatury antyczncj, „Meander” R. 38: 1983 z. 9, s. 329-336. W nawiązaniu do tematu niniejszej publikacji warto zauważyć, że Sygiert krytykowal Napoleona, niemniej przyjacielsko korygowat thumaczenie blizej nieznanych Wiersz) do Bonapartego, za co w niedatowanym liście z 1802 roku dziękował mu Antoni Pełka — zob. J. Snopek, op. cit., s. 210, 307. 
ducie. [...] Ten dziwak ma prospekt w swoim ogrodzie najpiękniejszy na świecie, żonę najładniejszą z sąsiedztwa i serce może najlepsze przy najognistszym temperamencic. Jest to czlowiek w 32 latach, który gral wielką rolę, byl sekretarzem w Radzie Nieustającej, rotmistrzem z pułkiem swoim, faworytem księżny L..., panem milionowego majątku, a naresztą straciwszy część jego wielką, że nie chciał przysiąc Moskwie, a drugą zmarnotrawiwszy, zresztą najlepszyn jest ekonomistą i kalkulatorem, lubo przy tym zawsze jeszcze rozrzutnym; przysłowie jego: „Raz żyję na świecie" (s. 164, przyp. 109).

Tenże Erazm Komar pozostawił w spuściźnie - bezwzględnie przerzedzonej zębem czasu, jak wynika z numeracji woluninu na karcie tytułowej - własnoręcznie spisany obszerny tom poezji pod tytułem Dor'u'zze moje zabau'y 1820 zebrane. Częśc $I I$, w którym wśród dowodzących sporej erudycji i pomysłowości poenatów okolicznościowych, rymowanych refleksji moralnych, wierszy obyczajowo-politycznych o zacięciu satyrycznym oraz czystej wody liryków (między innymi tlumaczonych z I Ioracego) odczytać można aż siedemnaście utworów zawierających bezpośrednie odwołania lub chociaż wzmianki napoleońskie. Wśród nich są cztery cykle epigramatyczne w gatunku inskrypcji „pod portret” (łącznie dwanaście epigramów).

Jak wspomniano, część utworów z tego rękopisu (znajdującego się obecnie w Bibliotece Instytutu Badań Literackich Polskiej Akademii Nauk w Warszawie pod sygnaturą IBL F. 176) pod kątem stosunku do legendy napoleońskiej omówił monografista krakowskiego oświecenia, ilustrując swoje rozważania wyjątkami z Dor'yu'zzych zabau' Komara. Porównując jego wiersze z odami Koźmiana, badacz zauważa:

Nie stanowią może całości o tak kunsztownej dramaturgii, ale podobnie jak tamte [czyli Koźmiana - J. W.] — poświęcone są Napoleonowi we wszystkich etapach jego niezwykłej kariery (s. 307).

Otwarte pozostaje pytanie, czy zestaw kilku wierszy Koźmiana, tworzonych w ciągu długiego piętnastolecia, powstałych każdy pod wpływem odmiennych i zmieniających się bieżących okoliczności, a związanych przewodnim "motywem heroicznym” odnoszącym się do osoby głównego bohatera, jest koliście domkniętym „cyklem” - dla którego czynnikiem konstytutywnym wydaje się scalająca myśl autora, zastosowana przynajmniej ex post, w trakcie komponowania i szlifowania wieloskładnikowego dzieła jako calości, jeśli nie istniejąca wręcz od samego początku, na etapie koncepcji, czego oczywiście nie sposób empirycznie stwierdzić w analizie historyczno- ani teoretycznoliterackiej — i czy jego domniemaną dramaturgię, wertykalne rozpięcie pomiędzy apoteozą a kondemnatą, można by zatem nazwać „kunsztowną”. Z punktu widzenia formy literackiej należałoby tu raczej zastosować „linearne” określenie „seria”, w której rozwój wewnętrznych poetyckich napięć, spostrzeżeń, postulatów i wniosków, dyk- 
towany wpływami zewnętrznymi, pozaliterackimi, może czasem przybierać kształt ewolucji czy nawet dramatycznego konfliktu, ale jej wyznacznikiem nadrzędnym pozostaje otwartość, niekompletność, gotowość na hipotetyczne dopełnienia - i z takim przypadkiem, jak się wydaje, mamy do czynienia u Koźmiana, który swoje powstające etapami ody napoleońskie, dokument straconych złudzeń i pogrzebanych nadziei całego pokolenia, pozostawil ostatecznie w artystycznym rozproszeniu. Co do Komara zaś (który również z utworów rozsianych na kartach swojej sylwy nie pokwapił się ułożyć domkniętej cyklicznej kompozycji), to dramaturgia jego stosunku do bohatera posiada rysy dynamizmu niewiele mniejsze niż w przypadku Koźmiana. Komar nie sadowi wprawdzie Napoleona na takich szczytach ubóstwienia i nie strąca go w tak głęboką przepaść potępienia, jak ze swoim herosem postąpił w odach Koźmian, ale jego myśli (bo są to glównie wiersze refleksyjne, intelektualne, mimo obecności w nich także akcentów emocjonalnych i wyrażeń modlitewnych) świadczą o burzliwej wewnętrznej przemianie nastawienia do „dumnego” w obliczu jego "upadku”. Co najciekawsze, jest to rozwój w kierunku przeciwnym niż u Koźmiana: od początkowych wątpliwości i jawnej niechęci do niebezkrytycznego uznania ważności osoby cesarza w historii naszego globu ${ }^{5}$.

Początki wyglądają dość typowo. Najwcześniejszym „napoleońskim” utworom Komara, związanym z wojną - by użyć maksymalnie ścisłego określenia - „austriacko-warszawską", skutkującą przyłączeniem departamentów galicyjskich do Księstwa (marszowa pobudka bojowa Do Krakourianóu' pod Austryja. 1809), oraz z kampanią rosyjską Wielkiej Armii (najbliższy formie ód Koźmiana dytyramb Przez pou'ód odezu'y gen. Kosińskiego 1812) przyświecają inspiracje tyrtejskie, płynące z bohaterskiej poezji antycznej i historii starożytnej - jak w parenetycznym wierszu Epaminondas czy przytoczonym za Rozmou'ami tuskulańskimi Cycerona (I 101) slynnym termopilskim epitafem Simonidesa. Katastrofa roku 1813, co również zrozumiałe, wywołała szereg gorzkich wypowiedzi poety-amatora, obejmujących zarówno nadrzędną przyczynę gwattownych zmian politycznych (Dumania moje w marcu 1813; $Z$ pou'odu cofania się Francuzóu' z Mosku'y. 1813), jak i ich przyziemne skutki w obrębie krakowskiej „małej ojczyzny" (W churilach ujeżḋ̇ajacych ministróu' do rejonu za Wistę na Podgórze 1813 roku rozwinięcie wątku z Dumań moich). Nie dziwi także wzniosły ton głosu Komara „nad grobem księcia Józefa Poniatowskiego", podobnie jak jego negatywna reakcja na przebieg i ustalenia Kongresu Wiedeńskiego (Do uprzedzonych. 1814; Dumanie moje $1814 \mathrm{r}$, z mottem z poematu Stanislaida Marcina Molskiego; szczególnie zlośliwy wiersz w duchu inwektyw Juliana Ursyna Niemcewicza Na wiadomość o Królestu'ic Polskim) czy późniejszy Wstęp do uiersza "Za dni moich. Przygody mojej ojcz)zzly” (być może świadomie

5 Inaczej niz Snopek (s.312), piszący te słowa uważa napoleonískie wiersze Komara za zapisane w księdze w porządku chronologicznym ich powstawania. 
utrzymany w romantycznej juz poetyce fragmentu, gdyż nie wiadomo, czy wzmiankowany w tytule utwór główny powstał ani czy w ogóle miał powstać). Tymczasem jednak po okresie niebotycznego entuzjazmu (niemal z prefiguracją bluźnierczej Wiclkiej Improuvizacji w wierszu $N a$ odgłos pourotu Napoleona z Elby) kolejne wiersze poświçcone cesarzowi skazanemu na wygnanie - najpierw na Elbę", a po „stı dniach” i Water$100^{7}$ na Świętą Helenę (wyspę-adresatkę retorycznych złorzeczeń Komara, urastającą pod jego piórem do rangi symbolu) - stają się wyrazem coraz większego współczucia i rozsądnego szacowania wszystkich „za” i „przeciw” w dyskusji nad postępowaniem upadłego (w sensie zarówno politycznym, jak i moralnym) władcy połowy Europy.

Gwoli prawdzie trzeba jednak powiedzieć, iż nie należy wyobrażać sobie eks-rotmistrza „z pułkiem swoim” Komara, skądinąd antydemokraty (i na równi antybiurokraty — co jasno widać z pełnych oburzenia przypisów do wiersza $W$ churilach ujezḋajac)ch ministróu" do rejonu...) — w mundurze jakiegoś „starego wiarusa” rodem z piosenek Bérangera, gdyż płynące z namysłu nad zmiennością i słabością ludzkiej natury przyznanie racji Napoleonowi nie determinowało jego oglądı politycznej mapy, po której szerszymi niż Bonaparte gestami kreślić poczęli monarchowie spojeni „świçtym przymierzem". Dlatego też na kartach księgi Komara znalazły się także czołobitne wiersze Do Aleksandra I Cesarza Wszechrosyi (rps s. 71-72), identycznie zatytułowana prośba „o ziemię, język, wolność, o prawa ojczyste” (rps s. 103-104) oraz długi poemat panegiryczno-dziękczynny Do Najjaśnicjszego Aleksandra I Cesarza Wszechrosyi, króla polskiego "' litym 1820 (rps s. 237-241).

Ten wyraz tęsknoty za stabilizacją polityczną łączy urozmaiconą formalnie i myślowo poezję Komara, spisywaną pro domo sua i rozpowszechnianą — jeśli w ogóle — zapewne tylko w stosunkowo wąskim kręgu przyjacielskim", z produkcją poetycką drugiego akademika z Krakowa, profesora Józefa Mosznowskiego, rodem z Moraw - jak przedstawia się w tytule jednego z wierszy lacińskich (interesujące nas wypowiedzi poetyckie ułożył właśnie w języku, który wykładał w krakowskiej „wszechıicy”). Ten mało znany chwalca trzech cesarzy, ale i piewca Wolnego Miasta Krakowa, w pozostawionym przez siebie rękopiśmiennym tomie Carmina (rękopis Biblioteki Jagiellońskiej w Krakowie, sygn. BJ $\$ 267$ II) wśród dwudziestu obszernych tekstów

\footnotetext{
"Snopek (s. 309-310) ryzykownie i raczej nietrafnie kojarzy związany z pierwszym wygnaniem utwór Komara Napoleon, opuszczając Francyje z katolicka pieśnią pasyjną Ludu mój, Indu...

Snopek (s. 310) blędnie twierdzi, że Komar nie wzmiankuje tej bitwy - o której jednak mowa w wierszu Pod portret Napoleona (inc. „Ten to dhugich lat ciagiem...”).

* Obecność w tym kręgu poety nowołacińskiego Mateusza 1)ubieckiego dokumentują skierowane doń wiersze na s. 128, 137-138 („z okazyi jego tacińskiego wiersza. Ad Erasmum Komar w dziele Sulbs'cina carmina, Cracoviae, pag. 60”), 258-259 („z powodu jego wiersza Momumentmm Thader Kościnszko") oraz wiersz z 1819 roku do bezimiennego przyjaciela, „Który mi przysłał wiersz Mat. Dubieckiego taciński, napisany na śmierć [Jacka Idziego] Przybylskiego, aby coś podobnego z tej okazyi napisać", ze s. 179-180) rpsu IBL PAN F. 176.
} 
166 Jacek Wójcicki

z drugiego dziesięciolecia XIX wieku zawarł sześć utworów ściśle „napoleońskich”, w tym trzy epigramatyczne epitafia postaci z obu stron ówczesnego teatru wojny: poległych pod Lipskiem Jeana Moreaı i Józefa Poniatowskiego oraz rozstrzelanego w 1815 roku Joachima Murata. Pozostałe trzy to: mitologiczna oda poświęcona kongresowi wiedeńskiemu, czyli doskonałej budowli opartej na trójkącie, tworzonej pod znakiem trzech cnót ewangelicznych (Carmen in congressum Vindobonensem trium Europae continentis Augustornm de unilersae pace pro stumma lege statuentium; 132 w.), spowiedź uczyniona na Elbie przez zesłanego już na dalsze wygnanie Napoleona, ujęta w formę elegii (Elegia confessionum Napoleonis I Gallormm Caesaris exulis in insula Elba anno 1815; 384 w.) oraz zawarta w strofach safickich poetycka wizja spotkania na Wyspie Świętej Heleny „byłego cesarza Francuzów” z... Jowiszem (Napoleonis I Caesaris quondam Gallorum cum Iove in insula Helena congressus; 128 w.).

Uczona poezja Mosznowskiego zarówno przez swoją treść, jak i wybór różnych form wersyfikacyjnych świadczy o zamiarze przekuwania bieżących wydarzeń politycznych w kształt jeśli nie wiecznotrwały, to w każdym razie przeznaczony do niejednodniowego zaistnienia w kręgu międzynarodowej elity intelektualnej. (Skądinąd nie wiadomo, czy jego wiersze kursowały drukiem i jaki znajdować mogły odzew ze strony czytelników). Pryzmat łaciny, języka nauki i literatury klasycznej, przetwarzać ma obrazy ze współczesności w dydaktyczne przykłady dwojakiego typu: z jednej strony chodzi o anty-parenezę, przestrogę plynącą z negatywnego postępowania bohaterów, z drugiej zaś o przykład dla piszących, jak oto można w dobie ekspansji języków narodowych twórczo pracować w językowym materiale wprawdzie szlachetnym, lecz niezwykle przeciez spatynowanym i zdawałoby się nienowoczesnym. Mosznowski, każąc Napoleonowi spowiadać się po łacinie ze swojego życia i plonów krwawego „żniwa”, na jakie cesarz wysłał posłuszne mu narody Europy, licząc na sprawiedliwą ocenę Europy, czy też każąc mu pertraktować z najwyższym bóstwem Olimpu, stara się żywą materię historii ująć w karby tradycji biograficzno-parenetycznej sięgającej starożytności. Czynny w realnym świecie (i w chwili pisania o nim nadal żyjący!) bohater przeniesiony zostaje tym samym w obszar mitu, postawiony w rzędzie wielkich, niesytych potęgi władców starożytności (takich jak przywolany w mottcie z Seneki Aleksander Wielki), na których wzlotach i upadkach uczyły się pokolenia.

Czy działanie łacinnka Mosznowskiego miałoby oznaczać tym samym uwznioślenie samego Napoleona i wyrażać uwielbienie dla niego bądź jego potępienie? Oczywiście nie; dystans stworzony przez moderujący filtr metaforyki, poetyki i retoryki lacińskiej oddala bohatera wierszy od bezpośrednich osądów, dając pochop czytelnikom nowożytno-starożytnego rymotwórstwa Mosznowskiego do patrzenia nań sine ira, dla nauki, jak na bohatera pełnych zamętu, krwawych a pouczających kronik - chciałoby się rzec: oczyma Swetoniusza i Tacyta. Dopiero następne pokolenia twórców spojrzą na Napoleona oczyma Szekspira. 


\section{Erazm Komar}

Rękopis Instytutu Badań Literackich Polskiej Akademii Nauk sygn. IBL F. 176: E[razm] K[omar], Dory'ucze moje zabau'y 1820 zebrane. Częś II

\section{Do Krakowianów pod Austryją. 1809}

Które podpiera, zdaje się, świat cały,

Tym już ramieniem dzisiaj jest wstrząśniony

Ów gmach potęgi, ów gmach okazały,

Gmach na ruinach naszych podniesiony!

Wybila zemsty godzina nareszcie,

Polacy! czas już, do broni się bierzcie!

Krwią się dobija praw, swobód ojczystych,

Ród wasz o ścianę walczy, więzy kruszy;

Dręczeni wpośród zniewag oczywistych,

Wy-ż zostaniecie bez serca, bez duszy?

Wy, co jak oni, krzywdo niesłychana,

Padliście tupem drugiego tyrana!

I jakże? gdy ich święty zapal wznosi,

Gdy im te ojców naszych czucia nieci,

Gdy matka z lzami o ratunek prosi,

Wy-żże być macie odrodnymi dzieci?

Chybaście z liczby jej synów wyrodni,

Chyba wolności jużeście niegodni!

O Maratony! o platejskie roty!

O Salaminy! Termopil dnie ztote!

Wy, świadki Greków odwagi i cnoty,

Natchnijcie w nas ich odwagę i cnotę,

Kiedy nas jeszcze dotąd nie zagrzala

Niewola własna ani przodków clıwała!

Bracia! czekacież, aż dumne Germany

Całą was swoją pokonają mocą,

Aż w cięższe jeszcze wezmą was kajdany

I w stan nikczemny ilotów obrocą? 
Wybiła zemsty godzina nareszcie,

\section{Tłumaczenie}

Dic, hospes, Spartae nos te hic vidisse iacentes

Dum sanctis patriae legibus obsequimur

Cicero ex Simonide

Powiedz Sparcie, przechodniu, żeśmy tu śmierć, blizny

Odnieśli za obronę świętych praw ojczyzny!

albo

Przechodniu! powiedz Sparcie, żeśmy tu polegli

W obronie praw ojczystych, którycheśmy strzegli!

albo

Powiedz Sparcie, żeśmy tı, rąbani na ćwierci,

Jej praw broniąc, walczyli aż do samej śmierci!

albo

Broniąc świętych praw Sparty, widze, gdzie stoicie,

Tuśmy za nie walczyli — tu stracili życie!

\section{Epaminondas}

Kto dawnych Greków weźmie przed siebie zwycięstwa,

Nie może nie uwielbiać ich cnoty, ich męstwa;

Ojczyznę, wolność dla ich serca przedmiot drogi,

Zda się więcej kochali, niż swe czcili bogi.

Lecz w równiach Leuktrów, Sparcie po zadanej klęsce,

Tu ja mantynejskiego wystawiam zwycięzcę!

Ponińmy jego światło, zasługi i czyny; 
Koniec jego, ostatnie zobaczmy godziny!

Tamto nam życia jego ciąg cały odsłania,

My patrzmy nań przed zgonem i w chwile skonania!

Patrzmy, jak z placu boju na bok uniesiony,

Własną ręką wyrywa grot w piersiach utkwiony!

Któreż serce tej tkliwej epoce wystarcza,

Gdy pyta zbyt troskliwie: „Gdzie jest moja tarcza?”,

155 Podaną gdy całuje, przytula zmartwiały,

Jak gdyby i dzieł swoich, i wspólnika chwały!

Patrzmy, jak radość z wrogów kraju uciśnienia

Siniejące już lice jeszcze zarumienia!

Usłyszmy głos, śmiertelnym dechem natężony:

„Nadto żyłem, bom nic był nigdy zwyciężony!".

Tak w prawdzie: od początkı do zawarcia powiek

I wielki byl bohater, i wielki był czlowiek!

Cudu potrzeba na to i wieków, ażeby

Świat miał coś podobnego, jak w nim miały Teby!!!

[s. 36-37]

\section{Przez powód odezwy gen. Kosińskiego 1812}

[przypis do tytułu:] 15 sierp. 1812 z I Irubieszowa"

Gdzież się zapędzam?... jakie zacieczenia

Tłoczą mnie w przestwór szeroki?...

Cóż mną pod niebios sklepienia,

Pod góme miota obloki?...

5

Tajemna wznosi mnie sita,

Nadludzka tclmienia wzmocniła;

Zachwycające słyszę objawienia,

Nadzieją płynne potoki;

Ludy! mojego stuchajcie tu pienia,

Boga się wola ziściła!

" 8 sierpnia 1812 roku generał Antoni Amilkar Kosiński na czele Dywizji Nadbużańskiej rozpoczął działania operacyjne przeciwko wojskom rosyjskim. 15 sierpnia to rocznica urodzin Napoleona (w roku 1769). 
Jego wam głoszę wyroki, Polska ożyła!!!

Twórczą dziélnością znany jej wskrzesiciel!

Co jej śmierć srogą zadali,

15

Co ją na części zszarpali,

Ten grom tyranów! ten niewinnych mściciel!

Mocą swojego oręża

Karze zabójców, zwycięża!

Liczne ich pułki już kryją mogiły,

20)

Twierdze zdobyla odwaga,

Ich krwią się pola zbroczyły,

Doznane męstwo przemaga;

Wszędzie ich zemsta sprawiedliwa sięga,

Wszystko z ich strony daremnem,

Krociowa pierzcha potęga,

Nasi rycerze za Niemnem!

Orzel, co zgubne pioruny wziął w szpony,

Białego złączył z Pogonią,

Czarno-dwóchgłowego gonią,

30

I już, już pada zemdlony!...

$\mathrm{Na}$ imię Napoleona

Drży cała Pólnoc strwożona;

Przeciwnie żołnierz wzmaga się zwycięski,

Zwiększa wrogom nieszczęść brzemię,

35

Już na wlasnę z sobą ziemię

Rozpacz unoszą i klęski,

A waleczni nad Dnieprem i Dźwiną w tej chwili

Znaki zwycięstwa utkwili!

Rodacy! to nam sama zawiść przyzna,

40) Przyznają wszystkie narody,

Że nas zwrócone swobody,

Że nas zbyt drogo kosztıje ojczyzna!

Oprócz niewoli w domowym siedliskı,

Co nam daly despot rządy,

Mimo oporu, ucisku,

Któreż kraje? morza? lądy?

Które są rady, sposoby pod słońcem,

Byśmy tam dla jej zdobycia 
Nie nieśli ofiar tym końcem

Z majątków, zdrowia i życia?

Lecz gdzie o wolność, o ojczyznę chodzi,

Nic się oszczędzać nie godzi.

Ale tak oba zdobyte przedmioty,

Te bezcenne dary nieba

55

Jeszcze uwiecznić potrzeba

Kosztem narodowej cnoty;

W tym zaś, w jakim dziś znajdıjem siç stanie,

Jest cnotą jedność, wytrwanie.

A Tobie, sprawco naszego istnienia,

60

Wdzięczność nie z powierzchnych znaków,

Lecz jak jest w sercach Polaków,

Tak przejdzie w krew ich plemienia:

Byt nasz, Twojego świetność majestatu,

Twoich dziel wielkość zogromni,

65

Cudem go nazwą potomni,

I za cud wskażą zdumialem światu!!!

[s. 49-52]

\section{Dumania moje w marcu 1813}

Libertas et virtus speciosa nomina praetexuntur Tacitus ${ }^{111}$

Co ja rozumiem przez ojczyznę?

Jaka z stanu dzisiejszego przyszłość?

I.

Ojczyzno! gdy cię zgłębiam siłami mojemi,

Drugim cię znam być Bogiem po Bogu na ziemi!

\footnotetext{
I" Fragment zdania z Publiusza Korneliusza Tacyta (Historiac IV 7(1): Cetcrum libertas et speciosa nomima practexumtur; nec quisquam aliemum servitium ot dominationem sibi concupinit, ut non cadem ista tocabula usurparet („Zasłaniano się zresztą wolnością i podobnymi wzniosłymi słowami, lecz ktokolwiek pragną̧ panować i innych niewolić, nie używał innych wyrazów").
} 
Nie z wrażeń ochełtanych, nie z mgłych znam cię śladów,

Jakimi są „popioły ojcowskich naddziadów”:

Ta pobudka niech głupców, niech wzrusza motłochy,

U mnie więcej los żywych niźli zmarłych prochy;

Im szacunek, im wzięte $z$ nich winniśmy bycie,

Dla tych, co są, co będą, wszystko - nawet życie;

Tamtym juz nic nie trzeba, tamtych byt skończony,

My mamy syny - córki - wnuki - męże - żony,

My ojców — matki — dziadów zgrzybiałej postaci,

Przez różne spadki rodu mamy siostry, braci;

My prócz tylu krwie związków, łączących nas wspoły,

Mamy naszych znajomych, nasze przyjacioły;

Bylby zaś kto, którego to wszystko nie budzi?

Jest on pewnie czlowiekiem... więc ma żyć dla ludzi:

A gdy tak, każdy światly bezsprzecznie to przyzna,

Że w szczęściu tylko żywych znaczy się ojczyzna!

\section{II.}

Cóż to mówię? niestety! w takim, jak dziś, czasie

Prawda i zbrodnią zwana — i na nic nie zda się!

Zapaleniec, tak nagły jak gwaltowna burza,

Odurzony sam czczością, drugich nią odurza;

25 Losy krajów, granice kryśli ręką wieszczą,

Wrzeszczy - dlaczego wrzeszczy? bo i inni wrzeszczą.

Hola! i moja lutnia przez zbyt slabe strony

Podobne jemu niegdyś wydawała tony!

Brzękałem, choć niezgrabnie, nuciłem bez wdzięku

Tę piosnkę, którąm złożył, i którą mam w ręku:

„Ojczyzno! na twe wspomnienie

Czule się serce porusza,

Jakieś bierze zachwycenie,

Jakoś się podnosi dusza!

Tyś jest drugim Bogiem żywym!

Każdy się tobą zajmıje,

I kto tylko jest poczciwym,

Ten zna ciebie, ten cię czu1je; 
Ow chyba twór znikczemniony

Wśród podobnych sobie wyzna,

Twór od cnotliwych wzgardzony,

Że gdzie dobrze, tam ojczyzna!

Prawy zaś przeciwnic powie,

Iz dla niej lube mu blizny,

Iż bogactwa, życie, zdrowie,

Niewolą są bez ojczyzny!".

Teraz dopiero baczny, ach, czemuż nie wcześniej!

Następną dodam strofę do złożonej pieśni:

„Nicwolą!... ale potrzeba,

Aby ta ojczyzna miła,

Jak jest drogim darem nieba,

Tak szczęściem żyjących była!”.

Ja chcę widzieć w ojczyźnie czystymi oczema,

Że ludzie ją skladają, a bez nich jej nie ma.

\section{III.}

Z chwil, w których się już właśnie wszystko nad moc sili,

Uwago, pozwól użyć jednej tylko chwili!

Pozwól z przeszłości, pozwól rozważyć powoli

Z obecnego dziś stanu stan przyszlej niedoli, A nadzieja, co blaskiem ciemnowidnych łudzi,

Niech już nie czyni igrzysk z dość nieszczęsnych lıdzi!

Na co się omamieniem próżnym sam człek ślepi?

Źle nam było... jest gorzej... i nie będzie lepiẻj!

Choć i granice zszerzy odglos jeszcze śliski,

I cóż stąd? — z ich zwiększeniem zwiększą się uciski!

A tam na ich wstrzymanie sposobów nie stawa,

Gdzie prawodawca musi milczącym być z prawa,

Gdzie satrapy, gdzie basze, gdzie władz naczelniki

W imieniu pana pany - reszta... niewolniki!...

Mówcież, czy to nie jedno w składzie rządu takiem,

Co imię mieć Polaka, a nie być Polakiem?... 


\section{IV.}

Uwago! moje pióro dla mnie ciebie kryśli,

Bądź cichym świadkiem prawdy mych przeczuć, mych myśli!

Unilknij; rzekłem wyżej, iż w podobnym czasie

Prawda i zbrodnią zwana, i na nic nie zda się;

75

Moment jeszcze!... a wszyscy, lecz niestety z łzami,

Zywymi - strach to wspomnieć! - będziemy świadkami,

Ze truciznę podaną nam w naczyniu złotem

Wypiliśmy dla zguby teraz i na potem!!!

[s. 57-61]

\section{Z powodu cofania się Francuzów z Moskwy. 1813}

Usque adeo res humanas vis abdita quaedam Opterit ct pulchros fascis saevasque secures Proculcare ac ludibrio sibi habere videtur.

Lucret[ius] de rer[um] hat[ura] l[iber] V v[ersi] 1231 et seque[ntes]"

Przed którym drżały narody i trony,

Co panujących panem się głosil,

Co królom z królów zdzierał korony,

Obcych i ród swój do nich wynosił,

5

Co świat zadziwiał zwycięstwy swemi,

Co swym skinieniem zmieniał mu postać,

Co się pod niebo wybil od ziemi,

I już, już drugim Bogiem miał zostać,

Cytat z piątej księgi poematu Dé rerum nutura Lukrecjusza (właśc. w. 1233-1235; za: T. Lucretius Carus. O naturze rzeczi', th. i oprac. G. Żurek, Warszawa 1994, s. 210):

Tak bardzo jakaś ukryta potęga miażdży człowiecze

Sprawy, wydaje się, jakby deptała wspaniałe rózgi

I groźne topory, jakby stroila sobie z nich drwinę.

Nad thumaczeniem epikurejskiego poematu Lukrecjusza w krakowskim kręgu literatów oświeceniowych pracowat wspommiany wcześniej Józef Sygiert (zob. J. Snopek, Nicznana karta z dziejón ośniecemiow 'ej recepcji literatur' antyczncj, „Meander” R. 38: 1983 z. 9, s. 329-336; M. Skrzypek, Lukrecjusz u' poezii filozoficzncj polskiego oúuricenia, „Przegląd Humanistyczny” R. 44: 20000 ur 3, s. 15-17). Przekladu swojego nie dokończył. 
Co chciał Marsowi koniec położyć,

10)

Którego sługą byla fortuna,

Co dumnę Północ mial upokorzyć,

A potem skruszyć berło Neptuna,

Ten — o raz jeden szczęściem rywalki

(Boże! tuś słuchał znękanych glosu!)

$15 \quad Z$ calą potęgą upadl bez walki!

I w przyszlej walce — zawist od losu?...

[s. 65-66]

\title{
W chwilach ujeżdżających ministrów do rejonu za Wisłę na Podgórze 1813 roku
}

\author{
...Arma tenenti \\ Ommia dat qui iusta negat \\ Lucan|us, Bellum cirile sive Pharsalia I 348-349|'2
}

Płaczcie, ach, przebóg, placzcie, ministrowie!

Stońce wam zachodzi wasze,

Prefekci! podprefektowie!

Raczej satrapy i basze!

5

Narzędzia ludów ucisku ${ }^{13}$,

Ich nędze zbierajcie w zysku!

Przepada wam rola żyzna,

Z nią dręczenia władza słodka!

Jaki chce los niech nas spotka,

10)

Lżejszym on zawsze będzie niż taka ojczyzna!

Ojczyzna, w której kilku kuło ciosy krwawe ${ }^{1+}$,

Ciosy niegodne Polaków,

12 Tłumaczenie ustępu z poematu Farsalia Marka Anneusza Lukanı: „Kto odmawia sluszności, i tak wszystko da uzbrojonemu".

13 Dzięki osobistym przymiotom i skłonnościom duszy niektórych z teģo rzędu urzędników, że nimi wiedzeni, miękczyli niejako i władzy, i z prawa powagi swojej twardość! [Przyp. autora]

${ }^{14}$ Konstytucyją Księstwa Warszawskiego mapisało kilka partykularnych, i jak niemylna wyrocznia nadali ją milijonom ludzi za prawo. Nadali ją narodowi ani do jego klimatu, ani do jego stosownie skłonności; narodowi, który nie zapomnial jeszcze, że był stanowicielem ustaw dla siebie, że Konstytucyja Trzeciego Maja i jego woli, i jego większości była dziełem. Był więc ten naród zdolnym (i tak przystalo, jeżeli miał być polskim narodem), aby sam sobie utworzyl prawa. Jeżeli zaś kiedy, to po doświadczeniu 
Poświęcała dzieci prawe

Na tuczny żér jedynaków ${ }^{15}$.

15

Ci nas, o żalu niestarty!

Uważali za bękarty!

Ci gwałtów, przymusu szykiem

Dla ratunku takiej matki

Wyciskali z nas ostatki

Żołnierz własny, ta pierwsza warownia narodu,

Chlebem rolnika żywiony,

Kutasami z tylu, z przodu

Za jego grosz przystrojony,

25

Dręczył jak nieprzyjaciela

Płatnika i karmiciela!

Powiedzcie prawdę, wieśniacy,

Ty, klaso ludzi spokojna:

Kto, nieprzyjaciel i wojna,

Rzućmy w ubocz rządzących i obrońców skutki.

Otwórzmy kodeksu prawa,

Dodajmy do smutków smutki:

$O$, jak tam straszna ustawa!

Jeden podsędek, mój Boże,

Niewinnego zgnębić może! ${ }^{17}$

Kiedy się tylko rozsrózy,

wad przeszłych doskonalej mógł je teraz utworzyć na przyszłość. [Przyp. autora]

15 Rozbierzmy uboczne dochody ministrów, a mianowicie skarbowego, popytajmy różnych poborców o różne składki, ofiary, i opłakany przez właścicieli, pod rożnymi powody i tytuly wniesiony, szczególniej zaś pod zbyt już ochełtanym „miłości i potrzeby ojczyzny”, policzmy publicznego dobra szarpaczów. [Przyp. autora]

10. Potrzeba by się wyzuć z uczuć i człowieka, i Polaka, aby mu rodowitość przyjemniejszą nad obcość nie była. Należy dla jej utrzymania chętniej położyć dwie części zapracowanego krwawym potem dochodu, niżeli dziesiąta jego część przywłaścicielowi kraju oddawać. Ale kiedy wszystkiego ofiary bez celu, więcej. bo dla uwiecznienia i niewoli, i nieporządku stają się, mażze je to lżejszymi uczynić, iż mi narodową mową z stolicy powiatu, kawałkiem na opalonym ożogu utkwionego żelaźca, zesłany wymęcza gwardzista? [Przyp. autora]

1- Między innymi tej prawdy dowodami weźmy przed się w powiecie jędrzejowskim okrucieństwa Bergskiego podsędka. [Przyp. autora] 
Na pięć lat jego prawica

Obywatela, dziedzica,

Tu to - w tym narodowość znajdowali ślepi,

I w zrównaniu wszystkich stanów! !x

Dziś czują, że było lepiéj,

Chociaż pod rządem Germanów,

45

Że było i bez przykładu

Mniej udręczeń, więcej ładu,

Że kosztem nieszczęsnej doli,

Majątków naszych użyciem,

Tysiąców mlodzieży życiem,

Lecz, Boże, ty się jeszcze wzrusz łzawymi modły!

Kiedy nam odjęte sily, Gdy nas nadzieje zawiodty,

Dla nich ofiary zniszczyly,

55

Niech nas Aleksandra ręka

Jako zwycięzcy nie nęka!

A jeśli twój wyrok Boży

$Z$ litości nad naszym stanem

Juz nam go przeznaczył panem,

${ }^{1 *}$ Biada ziemi, gdzie wyższość stanu ucisnąć zdoła najuboższego! Ta wieki bogdajby przetrwała, gdzie równość wszystkich, ale w obliczu tylko prawa, panıje! Lecz równość nagle zaprowadzona w kraj, którego (bolesno na to wspomnieć!) dziesięć jeszcze przynajmniej części ani czuć, ani myśleć nie umie, jest pierwszą zasada zamieszania i pierwszym gruntem złego; jest nareszcie przyduszeniem szlachetności i jej czynów w tych, których przodkowie i męstwem, i poradą, i uczoną wsławili się pracą. Zadrżatem na sejmie 1812 roku, kiedy w tej odwiecznej narodu polskiego praw świątyni, obok godnych swojego przeznaczenia osób, tam gdzie imię Zamoyskich, gdzie duch Rejtanów, Lubomirskich i innych tylu cnotami znakomitych Polaków unosiły się jeszcze, gdy tam, mówię, z miasteczek i gmin wiejskich niektórych spostrzegłem deputowanych!... o tempora, o mores! [Przyp. autora] 


\section{Na sejm w Warszawie odbyty 1812}

Bóg, który cuda, kiedy chce, czyni,

Gdyby powskrzeszał ojczyzny zbawców,

Gdyby ich wpuścil do tej świątyni,

Dawnych Polaków i prawodawców,

5

Ujrzawszy w niej skład nowego sposobu,

Rzekliby razem: „Wróćcie nas do grobu!”.

\section{Polak nad grobem księcia Józefa Poniatowskiego}

Ant illum nasci non debuisse, aut non mori Dictum de Septimo Severo ${ }^{19}$

Okryty sławą i blizny.

Książę! narodu zaszczycie!

Dni twoje szczęściu ojczyzny,

Jej chwale oddałeś życie!

5

Gdy srogie zwycięstw przemiany

Los na drugę stronę znęcil,

Uczczony chlubnymi rany,

Elstrę krwią twoją uświęcit!

$\mathrm{O}, \mathrm{z}$ najcnotliwszych pod sloncem,

10

Któryż Polak tez nie leje?

Aż dopiero twoim końcem

I on już skończyl nadzieję!

Tu drogie twoje ostatki

Od wiernej strzeżone sławy

15

Twej odwagi będą świadki,

I tej, coś jej bronil, sprawy.

„Nie powinien albo się rodzić, albo umierać” (powiedzenie o cesarzu Septymiuszu Sewerze za Scriptores historine Angustae XVIII 7). 
Tu serce smutek głęboki,

Tu żal przejmie dusze czlecze,

Tu każdy uczci twe zwłoki.

Westchnie do Boga i rzecze:

„O Ty, którego dobroć wyższa nad pojęcie,

Jeżeli jakę prośbę, to tę przyjn w momencie!

Prawy był syn ojczyzny, miłościa jej słynął,

Dla niej żyl, przy niej walczyl, za niç w boju zginąl!

Polak, króla potomek, mężny, skromny razem;

Więcej: byl dobroczynnym, więc byl Twym obrazem!

Boże, cóż nadto do Twej litości potrzeba?

Kto świata byl okrasą, ten godzien jest nieba,

Weź go na łono swoje!... posadź w pierwszym rzędzie,

Niech Cię wielbi, niech niebian twych ozdobą będzie!

[s. 81-82]

\section{Pod portret tegoż księcia}

Męstwem w kraju, za krajem, dla ojczyzny slynął,

Tam walczył i zwyciężył — tu walczył i zginą!!

W tym szczęścia i nieszczęścia wypadku dwojakiem

Dowiódl, że był rycerzem i że był Polakiem.

\section{Drugi raz}

Drogi cieniu! bogdajby śmierć twoja i blizny

Uczyły nas i kochać, i bronić ojczyzny!

Z wszech miar innych, sława jest doczesną i mierną,

Nieśmiertelnej ma sławy twoja cechę wierną.

[s. 83; Snopek s. 311] 


\section{Do uprzedzonych. 1814}

Dopókiż jeszcze, zwodzeni,

Nie wzruszycie się nad sobą?

Slabi i nieuleczeni,

Nadzieje waszą chorobą;

5

Nadzieje, o Boże mily,

Innym wierne, was zgubiły!

Mniemacie, że na Kongresie

Za wasze trudy i blizny

Wyrok mocarzy was wzniesie

10

Do wolności i ojczyzny;

Ani o tym myślcie, ślepi,

Wiedzą oni, jak im lepiéj!

Polska by istnieć dziś miała

W składzie Pospolitej Rzeczy,

15 Tak, jak niegdyś byla cała?

Tego zdrowy wniosek przeczy;

Życzę, lecz nie wierzę temu,

„Mocny nie zwraca słabszemu”.

Wreszcie, był Rzym, i nie ma go!

Nasz upad Niebo zrządziło;

Była i pyszna Kartago,

Byli, jakby ich nie było!

Cierpmy, a śmiertelny goniec

I nam samym zrobi koniec!

[s. 89-90]

\section{Dumanie moje 1814 r.}

Czemuż tak nędzny koniec świetnego początku? Molski, Panoun[anie] Sta[nistaua] Augus[ta]

Ojców moich ojczyzno! siedlisko naddziałów!

Ziemio i wolnych, i mężnych!

Przez niezgody twych synów, przez chciwość sąsiadów

Nikłaś potężnych! 
Nowy Cezar, bicz świata, ślepym wskazał zyski,

Zwycięstwy swymi się chlubił,

Durzył ślepych — a przez nich zrządzając uciski,

I ocznych zgubil!

Kwiat narodu, bo mlodzież, bo godnych wytracit,

10 Prócz utrat bez liczby innych,

Dhug swej dumy, dług własny wierzycielom spłacił

Kosztem niewinnych!

Sprawcy niedoli kraju! jak nań dziś patrzacie?

Jak na tych nieszczęść ostatki?

15 Na to dzieło opieki? Wy juz jej nie macie,

My naszej matki!

Światło nieba! ty Boską oświeć nas pochodnią,

Zły wróg nasz niech się nie śmieje,

Ufność odtąd w śmiertelnych, i niech będą zbrodnią

Nawet nadzieje;

Niech zwrotu swobód naszych chęć nie łudzi prożna,

Po co się omamiać cudem?

Gdy już być, jak się było, wolnymi nie można,

Bądźmy choć ludem!

[s. 97-98]

\section{Na wiadomość o Królestwie Polskim}

[przypis do tytułu: Z Wiednia doniesione]

Po tysiącach nadziei, obaw, życzeń, trosków.

Po krociach różnych mniemań, domysłów i wniosków,

Po ofiarach mień, życia i kraju trzecizny,

Rozstrzygnął się nareszcie los naszej ojczyzny! -

5 Już tedy mamy króla, i mamy mieć prawa;

Króla, którego wieńczą zwycięstwa i sława!

Prawa, rozumiem, dla nas do tyla swobodne,

Ile mogą najwyższej władzy być dogodne.

Choć sami z naszej straszni nie będziem postaci,

10) Po utracie rodzonych many starszych braci 
W rodzie Kirgów, Kałmuków, Baszkirów, Moskali,

Męstwo tych, tamtych światło zawsze nas ocali;

Ich słodkie obyczaje, szlachetne przymioty

Natchną w nas górnomyślność, narodowe cnoty,

15 Będziem wkrótce bez chyby (rząd sam to podnieci)

Tak podobni, jak gdyby jednej matki dzieci,

I gdy jak starsi bracia już staniem się tacy,

Rzeknie wtenczas świat o nas: „Oto są Polacy!”.

Wtenczas my wzajem rzekniem przed jego obliczem:

„Wieki Chrabrych, Zygmuntów, Batorych są niczem!

Tam ciemność, krajogubstwo, nieład, zniewieściałość,

Uszczuplały granice, targały ich całość,

Lud zaś pod panowaniem tyclı królów obrzydlem

Czymże był w miarę światła Północy? był bydłem!

25 Dziś dzięki przeznaczeniu, nie jak było dawniéj,

Będziemy oświeceni i wolni, i sławni,

A pod berłem ogromnej mocy i opieki

I wnuki wnuków naszych tak będą na wieki!".

\section{Napoleon, opuszczając Francyję}

Niegdyś waleczny, dziś ludı zhańbiony!

Już więcej chwały świat twej nie policzy!

Daleś wziąć sobie laur z niej upleciony

Grubym Germanom i północnej dziczy.

5

W wojnie, w pokoju, widzieliście zawsze

Moje zwycięstwa i usily prawe,

Przez krwawę pracę, walki jeszcze krwawsze

Zwiększalem wasze granice i sławę!

Męstwo bulawę dało w moje dłonie,

10) Koronę naród dla mojej osoby;

I rycerz w bojach, i cesarz na tronie,

Przydawałem wam mocy i ozdoby!

Dwa te zaszczyty, ciężaru i chluby,

Którymi prawnie do tej chwili władam, 
Ceniłem, póki honor wam był luby,

Wy go tracicie... ja obadwa skladam.

A w którąkolwiek los mną stronę rzuci,

Jakkolwiek moję przyszłość usposobil,

Mam pokój duszy, nic mnie nie zasmuci,

Wszystkom dla kraju, wszystkom dla was robil.

Chciałem dla świata i czleczego rodu

Wolności ludów w każdej epok porze.

Pragnąłem ciągiem mojego zawodu

Niepodległymi mieć zicmię i morze.

Czas i potomność aż po moim zgonie

(Czekam ich sądu z nadzieją i chlıbą)

Wydadzą wyrok o Napoleonie:

On li, czy naród sam swoją był zgubą???

[s. 113-114: Snopek s. 309 (w. 1-4), 310 (w. 5-16)]

\section{Na odgłos powrotu Napoleona z Elby}

Kiedy z wzgardą praw wszystkich, duchem sprosnej zgody,

Królestwa prawych królów i wolne narody

Jak płatki. które wicher po powictrzu niesie,

Despoty na wiédeńskim szarpali kongresie,

Kiedy ci ludogubce w ojcowskiej postaci

$\mathrm{Na}$ części rozłączali jednorodnych braci,

Gdy smutnym przeznaczeniem, jakąś sprzeczną marą,

Najsławniejsi najlichszych padali ofiarą,

Bo Gallów, bo ród Lechów, bo ród Włochów znany

10 Rus, Teuton i obmierzłe dzieliły Germany,

A stąd męstwo, stąd światło, narodowe cnoty

Mieszano w rody tchórzów, clytrości, ciemnoty,

Wtenczas wlaśnie, jak piorun, który ogniem pali,

Który z życia wyzuwa, który cedry wali,

Ręką Boga i barki wspierany Boskiemi

Grom tyranów, nadzieja ludów, szczęście ziemi, Jednym słowem: ten, co go unieśmiertelnia sława,

Na łono dziélnych Franków Napoleon stawa! 
Krok ledwo pierwszy czyni bohatera noga,

Duch w szarpaczach ustaje, zajmuje ich trwoga!

Wiodą przez morza, lądy na przybysza z Elby

Narzędzia śmierci, zbójców i zabójcze strzelby,

Pewni losu, jaki ich stąd w przyszłości czeka,

Zgromadzają pół świata na jednego czleka!

25 Takie dziś, gdy to mówię, wypadków są stopnie;

Ciekawym, która strona i jak swego dopnie?

Ale cóż jest w zlej sprawie za użytek z thumu

Naprzeciw sprawy ludów, wolności, rozumu?

Pewnie oręż odsieczy, przez wolnych wzniesiony,

30 Pokona niewolników platnych milijony!

Lecz gdyby szczęście poszło za ludzkości wrogiem?

Bóg znać nie dbałby o świat, przestał mu być Bogiem!

I jeżeli tyranów górę wezmą miecze,

Już i wolność, i światło przepadly, człowiecze!!!

[s. 121-122; Snopek s. 310 (w. 1-18)]

\section{Pod portret Napoleona}

Część świata wsparł, pół zbiedzil, trzy części zadziwil,

Cały bylby lub zniszczyl, lub też uszczęśliwil,

Gdyby go tylko było szczęście Lipskiej chwili,

A w Paryżu Francuzi sami nie zdradzili;

5 Dziś wniosek w politycznej zachodzi rachubie,

Czy zyskuje, czy traci świat na jego zgubie?

[Snopek s. 311 (w.1-2)]

\section{Inaczej}

Los lưdów - wolność przez nędze najkrwawsze,

Kosztem się nabywa wszelkim;

Jeśli miał ten cel, zostanie on zawsze

Nieporównanym i wielkim! 


\section{Inaczej}

Zrucał, utwarzał króle — burzył, stawial trony,

Wszystko niknęło przed jego obliczem!

I cesarza, i króla dwie stracił korony,

Z wszechwładzcy świata dzisiaj stał się niczem!

[s. 125; Snopek s. 311]

\section{Do Napoleona}

Wyższy nad wszystkie przygody,

Zasłużon Boga opieki,

Któryś zadziwiał narody

I będziesz zadziwiać wieki!

Choć cię wzięto z łona ziemi

Przez boje wojny najkrwawsze,

Światli jednak będą twemi,

Ty światłych będziesz na zawsze;

Choć na ciebie świata siły

10

I złe się wrogi zażarły,

Choć cię tronów pozbawily,

Slawy ci twej nie wydarly!

Co czuć i myśleć są w stanie,

W sercach tych ludów uczczona

15

Z wdzięcznością pamięć zostanie

Wielkiego Napoleona!

Potomne przydadzą lata

Do świetnych twoich dziel tłumu,

Żeś i wolności clıciał świata,

I panowania rozumu.

W Atenach, Sparcie i Rzymie

Bez ceny bylbyś był drogi, 
Święte by było twe imię,

A ty policzon wśród bogi!

[s. 126-127; Snopek s. 308]

\section{Pod portrety Napoleona}

Ten świat, który drżal przed nim, dzisiaj go ma za nic;

Tak każda wielkość niknie, kiedy nie zna granic.

[Snopek s. 312]

Nie będzie równego człeka,

Choćby świat stał bez lat miary,

Ani potomność daleka,

Że byl kiedy, nie da wiary.

Był świat, byli i ludzie; już w nim i w ich rzędzie

Nie było podobnego i nigdy nie będzie!

Czcią potomność przejęta, dzieły zadziwiona,

Wspomni Napoleona!

Rzadko szczęście jest trwałym, częściej jest zwodniczym,

Przemija sława wzniesiona,

I wielkość znika, i staje się niczym;

Patrzmy na Napoleona!

\section{Wstęp do wiersza \\ Za dni moich. Przygody mojej ojczyzny}

Rzeczono: „Czego tobie nie życzysz samemu,

Równie tego i nie życz, i nie czyń bliźniemu!”,

A ja mówię, że jeszcze winien w każdej dobie

Szczęśliwy uszczęśliwiać i podobnych sobie.

Mnie, co te dwie prawd czuje, mimo szczerej woli,

Ostatniej ziścić nie da nędza mojej doli. 
Cóż więc pocznę? Ach, wspomnieć na niemożność nudno;

Potomności usłużę, gdy współczesnym trudno,

Tę od dni mych im dalej czas późny odmierzy,

Może ona tym trudniej, co powiem, uwierzy, I nie dziw - wszakże i my tak czyniemy właśnie,

Częstokroć istne skutki bierzemy za baśnie.

Są, co przeczą, że Remus Romula był bratem,

Rzym że miewal cezarów, że władał pól światem,

Że z liczby milych Bogu Izraela synów

Oślą szczęką pokonał Samson Filistynów;

Stąd być może, iż przyszłość od nas oddalona

Zaprzeczy bytu, sławy, dzieł Napoleona,

Że Litwa, Ruś, Podole, Wołyń z Ukrainą

Wlasnością były naszą, Polaków dziedziną,

A co gorzej (bogdaj się nie zrodzili tacy!),

Może temu zaprzeczą zniemczeni Polacy!

Bądź co chce, czy nastąpi o to kiedyś sprzeczność,

Mój cel — przyszłych pokoleń dobro, użyteczność;

Myślącym są bezcenne naddziałów ułomki.

Słuchajcie mnie, odległych potomków potomki!

Jak morze, co ma wielkość przez wód wszystkich ścieki,

Tak z wiernych podań biorą światla późne wicki;

Słuchajcież mnie w głębokim milczeniu, albowiem

Polskie, mojej ojczyzny, przygody wam powiem,

Opowiem wam jej cnoty, z cnót następne skutki,

Na przemian jej ujrzycie radości i smutki!

Ta, co strzec, bronić dziélnie całości swej zwykła,

Własną i obcych winą niknęła... i znikła!

I znowu ten, co na czas świat w trwodze zawiesil,

Część jej przywłaścicielom dwóm wydart i wskrzesił,

A wskrzeszoną przy Gallów męstwie naszym męstwem,

Już nie Polską... ach, czemuż nazwano ją księstwem?

Teraz zaś przez zbieg zdarzeń ta kraju część mała

I króla, i królestwa tytuł odzyskala:

Pewnie to są zadatki, gdy Niebo poszczęści,

Rozszarpane do kupy pozgromadzać części,

A tron Piastów, dziś wsparty na tronie Północy,

Zanadto ma do tego i prawa, i mocy.

Lecz połóżmy nadzieje w przyszlych losów rzędzie,

To, co bylo, jest istne - to wnioskiem, co będzie; 
Ja zwracam przeszłość głosić; bogdaj z tej nauki

Korzystać potrafili wnuków naszych wnuki!

Bogdaj ich sławie, szczęściu, póki stanie słońca,

I przerwy, i przeszkody, i nie było końca!

[s. 165-167]

\section{Na wyspę Heleny}

Czemu cię picrwej przepaść, czemu bezdna wody,

Czemu nie pochłonęly morskie fale wprzody?

Czemuś wcześniej gwałtownym nie znikła trzęsieniem,

Nim bohatera świata stałaś się więzieniem!

5

Za co ten wielki człowiek wśród twojego łona

Ile tam godzin liczy, tyle godzin kona ${ }^{21}$,

Człowiek, co dobru ludzi oddal się bez przerwy,

Wspieran dziélnością Marsa, tchnieniami Minerwy?

O zdradnicze zbrodniego Neptuna narzędzie!

10

Ród człowieczy, I Ieleno, przeklinać cię będzie!

Ludów prawa, na jego potędze oparte,

Na zawsze już im z jej są upadkiem wydarte,

A tak zawistnym losem, gdy ta pękła wspolność,

I światlo zagasiła, i okuła wolność,

15 I aby do ich zwrotu kiedyś ślady starła,

Ostatnie szczęście życia, nadzieję wydarła!

Oby cię, skalo wszeteczna,

Panujących ci tyranów,

Kupczących twoich Brytanów,

20)

Hańba nie minęła wieczna!!!

Oby wam przez wieków wieki,

Co los narodów piastuje,

21" Wiadomo światu, jakie rządzca wyspy czyni mu aż do obelg przykrości. [Przyp. autora; mowa o gen. I Iudsonie Lowe] 
Co się nimi opiekuje,

Bóg (Z) swej usunął opieki!

Oby was za waszę winę,

Zdradne podstępy takome,

Jak Gomorę i Sodomę

Ogniem obrócil w perzynę!

Zrządź to, wszystkim wladny Panie,

Za karę i dla przykładu,

Niech ni cienia, ani śladı

Tych wyspiarzy nie zostanic!!!

[s. 173-174; Snopek s. 312 (w. 1-10; tytul przytoczony blędnie)|

\section{Pod portret Napoleona}

Niech go plami fałsz czarny, podchlebców olyda,

Nic jemu podobnego natura nie wyda;

Jak żołnierz świat zadziwiał walecznością cudów,

Jak czlowiek, choć monarcha, wolności chciał ludów,

Ten sam cel już go stawi w nieśmiertelnych rzędzie,

Stąd mimo swój upadek zawsze wielkim będzie!

\section{Pod portret Napoleona}

Ten to długich lat ciągiem przez oręż zwycięski

Trząsł światem, odmienil go, i zadał mu klęski.

Zrobił wiele - o, wielcz jeszcze by nie zrobił,

Gdyby go był Wellington z Blicherem nie pobił!

Od wlasnych sprzymierzonych hanicbnie zdradzony,

Walczył z siłą pół świata, padł wreszcie zwalczony!

Do sławy dawnych zwycięstw, co świat zadziwiały,

Ten sam jeszcze upadek pomnożył mu chwały. 


\section{Helena}

Non locus vimum, sed vir locum ormat

Adv $[\text { erbium }]^{21}$

Jest pytanie: Helena czyli będzie czczona,

Czy jej pamięć potomnych do wzgardy pobudzi

Przez powód uwięzienia w niej Napoleona,

Najgodniejszego tronu, największego z ludzi?

Podług mnie, skutkiem z celı niech zhańbienia czeka,

Tę dwójznaczność rozróżnić jest rozumu sprawą,

Z bytu zaś, choć w niewoli, takiego człowieka,

Pysznić się zawsze będzie, okryje się sławą.

Lecz świat, lecz późne wicki, głosząc przed wiekami

10

Zlę wiarę i szkaradność zbrodniczego czynu,

Słusznie wzgardzą Anglija, słusznie Anglikami;

Prawości! drżyj na samo wspomnienie Londynu!

\section{Mnie się zdaje}

Ja nie wiem, czyli moim zdaniem dobrze sądzę,

Czyli nim uprzedzony po części nie błądzę,

Co myślę, jednak powiem, o Napoleonie:

Więcej wart był z buławą nizeli w koronie,

5

I lubo postać świata zmienił z naszym wiekiem,

Większym był bohaterem nizeli człowiekiem.

$Z$ da się, że na ten wyraz każdy winien przystać:

Umiał zwyciężać, z zwycięstw nie umial korzystać.

Austerlitz, Jena miętkość dowiodły... a zatem,

10)

Czym byl, słusznie być przestał i władać pól światem.

[s. 184; Snopek s. 311]

"Tłumaczenie: ..Nie miejsce zdobi czlowieka, lecz człowiek ozdabia mejsce” (Przysłowie). 


\section{Ja tak myślę}

Bogu podobnych przed tobą nic było.

F. Wężyk Oda [zokoliczności ogłoszenia Polskid. 28 czenu'ca] 1812

Mial Rzym, miała Grecyja stawnych wielkich ludzi,

Ale ani on, ni ona

Nie miały Napoleona,

Darmo się wystawieniem równego świat łudzi!

5

Aleksander tron snadnie obalił Cyrusa,

Sam motloch przed jego okiem

Gubił się swoim natłokiem;

Rzymianów zatrważała odwaga Pirrusa,

I dłıgo ich nękało męstwo I Iannibala,

A dziélność jego oręża

Kapua tylko zwycięża,

Reszta bowiem drobiazgi, co Grek i Rzym zwala.

Gdy tymczasem przeciwko sobie Cezar Gallów

Doświadczeniem wyćwiczone

Wojska bitne niezliczone,

Na ich czele Pirrusów miał i I Iannibalów.

Wreszcie, gdy częścią świata Napoleon władał.

Poznaly wszystkie narody

Prawo człowicka, swobody,

I on właśnie całemu nowę postać nadał.

Mimo zwycięstw, co wieczną sławą go okryły,

Jego to dziełem jest przecie,

Któż mu był równy na świecie?

Bez twórczej tego zrobić niepodobna siły!

Wielkość innych przed jego wielkości obliczem,

Wyznajmy prawdą wiedzeni,

Przyznajcie, nieuprzedzeni:

Albo musi uklęknąć, albo stać się niczem!

[s. 211-212; Snopek s. 309 (w. 23-28), s. 311 (w. 28)] 


\section{Do przyjaciela}

Stój! na próżno się troszczesz, poczciwy mój Janie!

Prawe twoje zasady, słuszne narzekanie;

Ty clicesz, aby nadgrodą były uwieńczone

Cnota, męstwo, zasługi i prace uczone,

Gdy tymczasem mimo tych powodów prawdziwych

Los najczęściej utwarzał wielkich i szczęśliwych.

Gmin, chwila, okoliczność, zręczne położenie,

$\mathrm{O}$, wieluz to niegodnym nadały znaczenie!

A gdy ich traf, wynosząc, nad zacnych postawił,

Czcił w nich świat prawodawców, bohaterów slawił!

Do dziś jeszcze, niestety! ta maska nie znika,

My sami niejednego wielbim nikczemnika,

Wśród nas samycl niektórzy przez fałszów ogromność

Już zwiedli i współczesnych, i zwiodą potomność.

15 Kunszt pióra, pędzla, dluta razem się kojarzy,

Chwałą zbrodnie okrywa, ubóstwia zbrodniarzy.

Wiek po wieku wielkości, widząc ślady wszędzie,

$\mathrm{Na}$ wiarę poprzedników szanować ich będzie,

Przeciwnie niejednego, co był ludziom mily,

20) Niewdzięczność, zapomnienie przed nami zakryły!

Niejeden, co nam jaśnial, co nam był ozdobą,

Pamięć czynów szlachetnych wniósl do grobu z sobą!

Może kiedyś i przyszłość od nas oddalona

Nie wspomni cudotwórczych dzieł Napoleona,

Albo go, choć miał ludów dobro pierwszym celem,

Postawi obok Sylli, porówna z Kromwelem?

Otóz świat! otóż ludzie! jednakowi zawdy,

Otóż skutki podłości! otóż krzywda prawdy!

Nie troszcz się przeto próżno, poczciwy mój Janie!

30) Źle było od początku, do końca zostanie. 


\section{Nie zaprzeczam}

W którą się wzniósł, może on tej mocy nadużyl.

Lecz ileż się ludzkości nędznej nie przysłużył!

Tę, co się dziś jak koło z miejsca w micjsce toczy,

Pierwszy wolność narodom wystawił przed oczy;

Jedne już ją zyskały ludy przez te lata,

Drugie zaś o nię walczą we dwóch częściach świata.

Tak, ważąc złe, co przeszło, z dobrem nieskończonem,

Przeważy szala prawdy za Napoleonem. 


\section{Józef Mosznowski}

Rękopis Biblioteki Jagiellońskiej w Krakowie sygn. BJ 4267 II

\section{Elegia confessionum Napoleonis I Gallorum Caesaris exulis in insula Elba anno 1815}

Cunctane in aethereos abienut irrita ventos?

Cunctanc Lethaeis mersa fermutur aquis?

Ovid. lib. Tris. eleg. $7^{22}$

\section{Elegia}

Corsica me genuit, Respublica rebus adoptat

Imperii viduis Gallia me dominum;

Quae milhi dat vitam, genitrix fuit altera mater,

Dux, consul fio, consule Caesar ego.

Impero pro summa rerum quam prendo, quid illa?

Currit ad obsequium cum famulabus idem;

Subdita divinos Augusto pendit honores

Votivis alma praesul in ecclesia.

Quod vitare nequit, iam sic invita resummit

10 Excussum vano turba labore iugum.

Iuppiter omnipotens adducit primus habenas,

Ipse Deus populi rexque paterque sui,

E multis unum sibi deligit ipse regendum,

Sed fraenare genus non valet indomitum;

15 Aeternum servos qui mallent vivere regi

Quam sibi qua domino trudit in obsequium.

Quis iam Messiades populo speratus iniquo?

Si desit pietas, in fide nulla salus.

Inter inaequales libertas perdita mores,

20) Non est sub domino quae fuit ante Deo.

Indignum, famulum quondam ratus ille senatum,

"2 Motto z Żalón, (Tristia) Owidiusza (właśc. I 8, 35-36; thum. J. W.): 
Maiestate sua Caesare Nero fuit.

Quo non abiectae fert depravatio plebis,

Ipsos vel dominos pectoris Herculei!

Bubulcosne truces dederis, ni villice tauros

Des simul indociles indomitosque gregis?

Essent Attilae populis nisi culpa daretur?

Ni feriant, prosunt ferrea sceptra niliil.

Vulgus enim quavis in religione profanum

Quem colat, adstitium debet habere deum.

Iam vult, iam non vult, si quaeris, cur ita? nescit,

Ipsa voluntatis vis quia forsan iners,

Est vel natura per se vitiosa facultas,

Par ratio, puer est quilibet ecce suae,

Rite precaturus: tua fac, Pater alme, voluntas,

Fiat et arbitrii vana sit illa mei!

Quae non perdidimus propriam servare volentes?

Omnia; sic nil sunt onnia quae volumus.

Quid ratio, dux arbitrii, potiorque facultas?

40 Conflictu multo vincitur illa gravis;

Cordibus humanis affinis sanguine sensus,

Naturae votis auxiliaris adest,

Impellit teneras, fundit molimine mentes,

Quas tardis ratio motibus ire iubet.

Omnibus una quidem vis est, ast integra nulli,

Pervulgata magis quam bene nota cui.

Imus quo trahimur, sine motu nulla voluntas,

Calcar equum stimulat, quemque libido sua.

Lubrica vasa sumus, diversos limus in usus

Pro modulo summi compositus figuli.

Est sua mortali vis acquisita cuique,

Est ratio qua fit conscius ille sibi.

Ast paret fatis humilis, non imperat illa,

Stultitiis hominum frangitur urna cito.

Sunt peccatorum numero capitalia septem ${ }^{2.3}$

E Tridentino nata patrum gremio

Edere quae nossent, ignorant tollere sancti

Custodes mortum noxia pontifices;

23 Superbia, avaritia, luxuria, invidia, gula, ira, acedia. 
Orabit caelcbs, qui non vult clericus uri,

$$
\text { Nam Deus oranti non negat auxilium, }
$$

I Iac pietate patres hortantur spirituales,

Sed naturales, quod scio, filiolos.

Mores expectant octavum prodigiorum

At desunt habiles artifices operum.

Quae destructa iacent veterum monumenta per orbem,

Nec pro parte valet condere posteritas.

Sancta licet sedes Petri, sed Roma beata

Non sic in populis est hodierna suis.

Gallia tum statuo, fiet quod scilicet olim,

Magna sub Augusto Caesare Roma fuit.

Sufficit unius maiestas solis in orbe,

Cur non Europae solus et unus ego?

Sunt vespillones nati nataeque parentum

Reges Europae, sunt totidem patriae.

75 Bellis succumbet mater, nanibusque suorum

$\mathrm{Ni}$ teneat plures unus in officio.

Dixi, proposito cedit fortuna labori,

Per Lodi pontem ducor in Italiam,

Alpes transcendo, celeri Pirenaea meatu,

80 Trans mare, trans amnes, flumina magna feror.

Hostis ego visas perrumpo concitus alas,

Nunc aestu, nunc vi, praecipitante mora.

Gallus certus ibi quod vincet me duce, Gallo

Sic ego, quod vincam, milite certus eram.

85 Franges temonem, perdes, auriga, flagellum,

Si vehemens celeres exagitabis equuos.

Dixi; percutio, velox ut Phoebeus axis

Phacton et in proprium, sic feror exitium.

Odit quae populus, quae aliis nocuere resummo,

90) Usus pro summo viribus arbitrio,

Quin metuam laesum, vindictam summere suetum,

Par foret ob causas, et mea culpa pares.

In medio virtus, ubi non, ut debuit iret,

Adversae sortis sum reus ipse meae.

95 Mens animusque mihi truculentis omnis in armis

In solo pietas Marte fidesque fuit.

Quaqua versus humum devasto ferreus omnem,

Reddo sepulchralem funeribusque gravem; 
Hoc colit Europam, dum scindit miles aratro,

100 I Iac ego falce suas colligo messor opes.

Germanis ad opus, feudalibus atque Polonis,

Utor et I Iispanis, Italiae populis.

Depositis solio iam vi, iam fraude monarchis,

Nil profuturos, procreo Marte novos.

105 Quid iuris? fortis non est inquirere Martis,

Illius in templo lex, mulier taceat:

Legislator ego, populis qui sancio leges,

Napoleon codex summa caputque rei.

Quid mihi cum fatis? quid quod sua Bellerophontem

$110 \quad$ Praecipitant spatiis aethereis equitem?

Sunt aliis rursus quandoque faventia quaedam,

Scilicet ob causam sunt bona fata bonam.

Non curat tristes aliorum gloria casus,

Quo plus obstiterint, altius urget honos,

115 Ille suo fretus consurgere funere maior,

Heroem facinus laudat opusque suum.

Quale meum quantumve fuit, videamus oportet!

Virtus est armis, est et Evangelio.

Ad pacem gentes velut alter apostolus hortor,

120 Exemplis regum tristibus admonitas.

Attoniti quae reddo stupent oracula multi,

Confirmata meis singula prodigiis,

Inviti quamvis, metuentes numina, parent,

Obturant humili colla gravata iugo.

125 Perfert ingenio respublica domta tyranni,

Plectentem patiens osculatura manum;

Ut fuit effrenae breve, iam durabile contra

Percussoris erit, sic reor, imperium.

At gravitate sua libertas dum cadit, hostes

130 Reges et populos obruit illa suos.

Iura malis quid? summa bonis iniuria, praedae

Sunt motiva lupis qualiacunque scio.

Afflictos charae reddet Bonaparte Sioni,

Nomine concipiunt spemque fidemque meo.

135 Quantum non vigeo, quantum non audeo consul!

Votis prosperitas cedit amica meis.

Civica sollicitae si quando pericula vitac,

Intestina suis bella cruenta focis 
Urgent, appello felix egressus Egypto,

Servandis Gallis aeneus anguis eram;

Pro me Neptunus, contra me navita Nelson

Stabat capturus qua feror ille ratim.

Infernalis ibi moles explosa fragore

Tardius errumpit praetereunte mora;

145 Nec me Drache Anglus, Bavarum legatus in aula,

Audax nec iaculis Gallus arena ferit,

Iura quousque mohi, libertas sacra fuere,

Et sacra maiestas consulis ipsa fuit.

Ingenio vis est, fortunae maxima, iunctis

150) Heroes fimus, credulitate dii.

In duce caeca suo rationem compede vinctam

Ducit cum morum religione fides.

Quid princeps multis, qualis speratur ab aevis

Qui necdum paret Messiades populis.

155 Erigor in statua cum posthac more deorum

Qualem vix habuit Iuppiter ipse stator,

Applaudit populus mutato nomine Caesar,

Plus sibi Napoleon quam Bonaparte placet.

Vult reddenda sibi Mariana rosaria, reddo,

160 Sit faenum patriis pace mea vitulis!

Ipse fidem populi declaro nationalem,

Illius ut placita religione colar.

Mahometanus eram, nunc catholicus, nihil obstat,

Finis sit melior, dummodo posterior.

165 Ite, sacer clamat, votivis praeco peractis,

Missa est! signatus mox ita Carnot abit,

Audax imperii protestans credulitatem

In divum Augustum reprobat ille piam.

In castris miles ludensque exercitus armis

170) Sol paret viso Caesare, clamat ibi.

Excitat ad palmam legiones nummus honoris,

Irent ad facinus quodlibet Herculeum;

Cantabat Gallus, bene tum strepitantibus alis,

Hostem cum victor sternit aduncus humi.

175 Ipse mihi populum spoliis devincio multis,

Militiae magnos muneribusque duces.

Quidquid Pantheon pretiosi continet in se

Et monumentorum, debet hoc ille mihi. 
Omnia quae capio, cum Gallis divido, practer

$$
\text { Unum indivisum Caesar ego solium. }
$$

Libera sed pauper respublica divite trusa

Sic domina cecidit repudiata viro.

Leges humano scribit pro iure potestas

Ut semel in manibus volvitur urna suis.

Nullus inhumanis modus est affectibus, instant

Moribus aeva bonis, aurea non redeunt.

Semper venalis stat res humana sub hasta,

Iam sumus unius, iam sumus alterius.

Imperii summam, non iura politica curat,

Legibus est varium quod schedulis pretium;

Quo plures cudit sapientia vana recentes,

Sunt nova, sunt primis deteriora malis.

Idolum factus Gallis aliisque colossus,

Grandis adhuc videor, non satis esse milhi,

195 Regum Caesareis gravis auxiliaribus unus

Ambire Europam constitui pedibus;

Certus, si venio, video, si pugno, triumpho,

Fama repercusso nomine magna meo,

Virtus I Ierculei fortuna comesque laboris,

200 Consuevere suis altius ire locis.

Bis captam cessit nummis spoliasse Viennam,

Inde mihi salvum, bis retutisse pedem.

Occupo Berlinum, percussa Silesia falce

Rasa stetit campis divitiisque suis.

Dimoveo Russos mili positione minantes

Victor dum separo, foedere iungo milhi,

Sed cito mutatis quodam discrimine rebus

Instabilis fractae culpor amicitiae,

Omnem perdo fidem qui perfidus omnibus essem,

210 Res misera omnis homo qui pietate caret.

In portu stabat firma res Anglica terra,

Quo plus impedio proficit illa magis;

Oceani nautas a litore et arceo portu,

Ultra quos ipsi non licet ire mohi,

215 Oppono frustra profusis arma guinis

Iacturam facio pulveris empirei,

Immobilis donec sic viribus haereo fractus,

Ut mea Abukireis classica puppis aquis 
Aequor et inter humum sic lassus carpo quietem, Inter et uxores vir mediusque duas.

Postquam dira fames praedae pro more leonis

Extenuat stomachum, torquet et extu gravis,

Assurgo nemorum violentior Attila strage,

Ultra Sarmaticum Mars iubet ire polum;

225 Ignem longinquis Moscovia cepit in oris

Ardet et in flammis Ucalegon medius,

Quaerens si qua liber adhuc, si qua pede salvo,

Praeceps accensis exeat ipse focis.

Expers consilii, praeterquam vertere terga,

230 Et foedam velox accelerare fugam.

Agmina quae duxi Russis fundenda relinquo,

Iam rigido trado conficienda gelu.

Donec Marte recens subsisto alatus ad Albim,

Ast iterum victus litora mitto Rheni,

235 Quo passu tutos a tergo, Gallia, fines

Felici possem reddere Marte tuos.

Viribus inferior, nil contra quattuor unus,

Ingenio notis proficioque dolis,

Deficiunt a me reges populique Rhenenses,

240 Vestphalus et Saxo, deficiunt Bavari.

Turpiter Hesperiis eiecto milite Gallo,

Iam quod restituam, nil aliis habeo.

Vincor, sed vinci malo quam cedere fatis,

Pacis et adstringi conditione data,

245 Omnia si Caesar, quoniam sic fata tulerunt,

Maior nil perdo Caesare Napoleon.

Gallia quid? metuit sibi, non mihi, qui metuendus

Proclamatus eram, quolibet hoste magis,

I Iannibalem portis, solioque repelle tyrannum,

250 Patria non dominum, quaerit at illa patrem,

Dicunt: offensus tali sermone repono:

Arbore confecto, quid milhi cum solio?

Caesaream ligno pluris non aestimo sedem,

Mecum Parisiis occidit omme decus.

255 Non egeo populo, sed me magis indiget ille,

Gallia magna mea facta labore fuit.

Immemor eiectis quae dixi regibus ante,

A vobis regnum transtulit ipse Deus, 
Credunt Attilam, si Numinis esse flagellum,

Oderunt hominem carnificem populi.

Quis finis rerum, quas inconsultus agebam?

Quae confundo creant nil elementa boni.

Non qui audet magnus, sed qui ommia perficit heros,

Fecit nostra procax irrita cuncta manus.

265 Omnibus unus enim mortalis nemo regendis,

Sufficit et sapiens nemo vel ipse sibi.

Pendimus efeudis, ingrata census arena,

Nempe cupidinibus nemo suis dominus,

Respondent curis tantisque laboribus aequa,

270 Optatis nunquam faenora temporibus.

Ipsam fortunam comitem quam semper habebam

Stultus inextortam credo tenere manu,

Nec iam consilium curans in fine meorum,

Magno me parvum fecit in orbe meum.

Maximus heroum communi voce citabar,

Sed non magnanimus pectoris Herculei,

Indulgens raro, iudex plerumque severus,

Iuri trado reos armigeris proprio.

Scilicet in magnis magnum inclementia crimen,

280 Maiestas vitio laeditur ipsa suo.

Victima bellorum, populi respersa cruore,

Multorum culpis et gravis illa suis,

Vix aliquando magis maledictus ab omnibus alter,

Hircus perpetuum trudor in exilium,

285 Elba capit dominum quem non Europa valebat

Integra limitibus continuisse suis.

Inter tres socias venatrix Austria captam

Inclusit caveae magna Statoris avem.

Si quod vivo, tibi gener, Austria, debeo, salvus

290 Foederis hoc socius debet uterque tibi;

Vixissent quasi non essent, ille remotis

A nobis campis alter in Elyseis.

Publica privatis praeferre negotia curas,

Ut reputes contra, res nihil esse tuas.

Victima votorum carissima nata tuorum

Occidit en Gallis sidus Austriacum!

Ex pacto sociis, quae perdunt, omnia reddis,

Natura iunctos exuis ecce tuos. 
Dignus adoratu Ludovica matre Maria Infans progenitus Napopleone patre, Cultores reges, ut nascitur. invenit artes, Cantat "In excelsis gloria" Musa "Deo!". Aspergens hysopo cunas pannosque sacerdos, Servi servorum fungitur officio, Quid nunc? mortuus est mecum civiliter ille, Rex bello nactam perdidit Italiam.

Plus logices, quam forte putas, pietatis Achivae Pravi rectores orbis habere iuvat.

Peccabunt reges in publica commoda semper, 310 Dum removes praesens, bella futura para! Audaces faciunt, non terrent fata sinistra,

Qui gaudet casu, proficit ille meo.

Obtigit heroum mihi sors, fortuna laborque,

Obtigit et finis gloria nempe brevis.

315 Audit sol terris, qua lucet parte, benignus,

Non qua comburit fervidus ille plagas.

Ast ego, mutantes imitatus regna cometas

Alta, quem stupeant, in regione poli,

Orbem caudata rarus percello figura,

320) Ingenii vanum praeteriensque decus!

Quo plus in gestis argenti comparo bellis, Museum raptis artibus accumulo.

Gallia plus nullo sub rege gravata tributis, Moeret, et in populo depopulata suo.

$325 \quad$ Felix dum tento reserare meatibus Alpes, Pervius est structa Cenis ibique via. Aedifico naves, struo portus, flumina iungo, Haec tam magna stupent artifices opera.

330 Qui cecidit numeris et gravitate sua.

Scilicet in magnis Gallo inconstantia rebus,

Sensus ad extremas est nimiumque levis,

A quavis sperat vulgus novitate salutem,

Sed fallit miserum spes levitate sua.

335 Gallia quod mulier, iam pandit blanda favores, Iam magis offenso saevit et hoste mala,

Felix ut quercus iam magna mole superbit, Iam cadit adversis rebus arundo levis. 
Laudat carnifices Roberspierum [!] atque Maratum,

Qui sibi tum princeps papa simulque fuit,

Promulgant mentes immortalesque deosque,

Quo plures facerent exanimes hominum.

A magnis magnum vitiis memorabile vulgus,

Girondistarum seditiosa lues.

345 Anxia proscriptos ad reges turba recurrit,

Ut puer ad ferulam, Copta trucesque Baios.

Emersura minus quo concita fertur abysso

Roma carens Fabiis est peritura brevi.

Est opus effrenae forti domitore procorum,

$\mathrm{Ni}$ vis lascivam reddere prostibulam.

lura reluctantes iam nunc aliena fatigant,

Regia Caesareis sunt graviora malis,

Libertate frui, sapientia defuit illis,

Non unus dominus, sunt modo quinque reis.

Fusa mea bellis, fateor, sunt agmina culpa.

Sed non es culpa, Gallia capta, mea.

Hostibus ut charis te libera dedis amicis,

Urbe graves recipis praesidiisque tuis,

Iam semel atque iterum, plus nempe vereris ab uno

360 Quam multis; quidni nata es ad obsequium?

Quid populus? Caesar si me non indiget, inquit,

Sit nunc exilium, non moror, Elba, suum!

Subscribit votis maiori parte senatus,

Eiecti miseret Martia sola ducis.

365 Tempore quo clausus, diversa negotia volvo,

Illa Viennensis publica concilii,

Impellunt, si quo, iunctorum foedere vanum,

Reddere Marte queam, Machiavellus opus,

Parisios revocant suffragia caeca repulsum,

370 Elba, ut Bucephalus, prosilio stabulis.

Liber et armatus perrumpo Acheronta, fugato

Rege, resummo meum ferreus imperium

Proscripto faciunt usurpatore nefandum,

Infractae stabilis pacis in orbe retum.

Audax aggredior, multis legionibus impar,

Et video fusas ad Waterlohe meas.

Fulminis ictus erat, qui Helenam mediumque repellit

Me procul Oceanum; fac, Europa, vale! 
Gaudia dissimula, nec sic aliterque loquaris,

Rite socer sapiens, hoc monet ipse meus.

Ne propere gavisa mea, quod non precor exul,

Conditione foret sors tua deterior.

Tunc me condemna, sine me si quando bearis,

Tunc defle, sine me, dum minor extiteris.

[s. 12-35]

\section{Epitaphium ducis quondam exercitus Gallici \\ Moreau in bello ad Dresdnam caesi}

Exul in Americam patriae sum mortuus heros,

Inde redux armis vindico dux patriam,

Et cado; deflendus Russis commilito iunctis,

Ultores causae quos reor esse bonae.

\section{Epitaphium principis Iosephii Poniatowski in bello ad Lipsiam in flumine extincti}

Princeps, Sarmaticae dux gentis, Horatius idem,

Sorte Curiacius, non ego Marte cado.

Tu quisquis patriae flagrabis amore viator,

Sit mihi, dic, melior scilicet illa Deum! 


\section{Napoleonis I Caesaris quondam Gallorum cum Iove in insula Helena congressus}

Nec hoc Alexandri tantum vitimn fuit, que'm per Liberi Herculisque vestigia felix temeritas egit, sed onnnium quos fortuna irritavit... quem innenies, cui modum imperii satictas fecerit? Sencea lib. de benef.

\section{Ode}

Puppis adversis agitata ventis

Fertur in Scillam fugiens Charybdim

Luctuosam nos Helenam procella

Iecit ab Elba.

Quae fides rebus nimium secundis?

Quo deum ducunt, populi favores?

Ingeni virtus, gravitas, honores?

Aegida Pallas

Praebet heroi, populis datura

10

Herculem, Phoebum miseris putares:

Exuunt magnos numeris bonisque

Numina reges,

Nec ferunt terris aliquod iuvanen,

Leucadum gentes revocant beantem;

Quod pares non sint studiis deorum

Inferiores,

Nec sinunt, esses populis flagellum:

Culpor eversi socialis aevi,

Imperi summa, proprio deorum

Iure potitus.

Iuppiter, num tu vel ego reponit,

Imperas? numquid tibi regna parent?

Sunt honor, virtus, timor et deorum

Aegida regum. 
25 Rex ego regum, dominator orbis

Sum deus cunctis populis paterque,

Qui meos audax tetigisset unctos,

Ille profanus.

Ut nequis fatis hominum mederi,

30) Arduis sic tu nihil adde curis:

Artis hic summus modus est regendi,

Unus et aequus.

Marte quid prodes? cadit in ferocem,

Gentium clades, violata rerum

35

Prisca maiestas, cadit omnis atra

Culpa malorum.

Quis fuit maior Bonaparte nuper,

Dux et in bellis, et in urbe princeps?

Quis modo magno minor est cadente

40)

Napoleone?

Elevat fortes moderata virtus,

Deprimit, fines nisi servet aequos;

Surgit heroum sapiens parato

Austria casu.

$45 \quad$ Nec reluctantes ferit illa partes,

Sed nec inquirit; populi favores,

Caesar indulgens, bonitate ductus,

Quaerat oportet.

Villicus villae, ratiocinator

50 Tu meae, sed non dominus fuisti,

Ius meum, Caesar, sine te gero, nec

Divido tecum.

Veritas vanos Helenam repellit,

Hanc super petram tibi pono sedem,

Stabis infractis I Ielenista portis

Tutus in aede. 
Contine diras vehemens querelas,

Iuppiter magne! populi voluntas,

Vox Dei, dignos meritis honores

Ceptis arrides bonus ipse rebus,

Prosequor tentans graviora, quo plus

Tir faves: quem non stimulata virtus

Altius urget?

Imperet Caesar nisi rite magnus?

Proderit multis fuerit quin heros?

Tu ne componis nisi fulminando

Iuppiter orbem?

Pro tuo reges modulo beati

70 Imperant, nactis ad opus ministris,

Imperaturos meliusne plures

Dixeris uno.

Foederis virtus pietate Martis

Nixa pacem sic redolet sub hasta,

Ille emit charam populis brevique

Vendit et alter.

Me, quod adduco, removes, habenas,

Et relaxatas aliis remittis,

Quos mea, tutos facies periclis,

Ipse repulsa.

Austriam pacem sequeris daturam;

Illa quod regnis removet propinquos

Tu Pater quaesto populos ab aevo

Nempe Saturni.

85

Usque pax bellis magis est paranda,

Quo minus multis sociisque Martis,

Atque praesenti sapienter horae

Fidere possis. 
208 Jacek Wójcicki

90) Tu viros mavis removere fortes,

Quam super petram tibi civitatem

Ponere firmam.

Ut volo, sic fit: ratio deorum,

Pura, respondes, putaque est voluntas,

95 Simius stultis imitatus almam

Gestibus haeret.

Si nec humana ratione mundus,

Nec regi gentes poterint labantes,

Quod bonae nullo fuit aequus heros,

100 Tempore causae,

Vel procul lapsam fugiat triumphus:

Ad voluntatem taceo deorum,

Iudicans vanam propriam cuique

Inferiorum.

105 Corda te regum manibus tenere,

Quas lubet partes ita vertere inquis,

I Ioc meum sentit, Iovis iracundo

Fulmine, saxo

Pectus illisum. Cecidi favore,

110 Non ego causa careo patrono,

Imperi stabit gravis usque summa

Villa sub hasta.

Iam dii magni, modo iam minores

Rebus intersunt hominumque fatis;

115 Prodit in quavis aliquis sequenti

Histrio scaena.

Sic ibi partes truculentus heros,

Ti tuas finis: populus deorsum

Clamat offensus, pereat protervus,

Foederis hostis! 
Albiae captas dominae favores,

Et gener magnae sine labe vivis

Austriae, quod sunt tibi nempe debent,

Utraque victo.

125 Haec tuae spes est Helenae salutis!

Fata fert magnus patienter heros;

Tempus ut res est pretiosa, summes

Robur ab illo.

[s. $45-56]$

\section{Epitaphium Ioachimi Murat capti et ex sententia bellica ferro percussi Neapoli}

Regis et herois tum Marte favente creati,

Ferro depositus, hic tegit exuvias

Limus Ioachimi: tu qui legis ista, memento:

Vicit Ferdnandus [!] rex bonitate Dei. 